(0) 1986 Is 電気化学的測定法による高温での鋼中水素の 検出

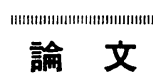

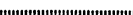

椿野倩繁* ·安滕敦司 ${ }^{* 2} \cdot$ 増出 尚*3 $\cdot$ 山川宏二*

\title{
Detection of Hydrogen in a Steel at Elevated Temperatures by an Electrochemical Method
}

Harushige Tsubakino, Atsushi Ando, Takashi Masuda and Koji Yamakawa

Synopsis :

An electrochemical permeation method using molten sodium hydroxide is presented to detect hydrogen in a steel at elevated temperatures $(673-773 \mathrm{~K})$ in the range of practical interest for hydrogen attack.

The results are as follows :

(1) The most suitable potential range to detect hydrogen is from -0.8 to $-0.6 \mathrm{~V}$ vs $\mathrm{Air} / \mathrm{O}^{2-}\left(\mathrm{ZrO}_{2}\right)$.

(2) The experimental permeation curves for specimens with thickness above $4 \mathrm{~mm}$ agree fairly well with the theoretical ones.

(3) Diffusivities of hydrogen in the steel $6.5 \mathrm{~mm}$ thick in this study are in good agreement with the values obtained from a usual gaseous method.

(4) The detection limit of hydrogen content in the steel in this study is less than $0.1 \mathrm{ppm}$.

(5) Therefore, this electrochemical method will be usuful to predict the hydrogen attack of steels.

\section{1. 緒}

高温・高压水素壊境下では, 鉄鋼材料は水素を吸蔵し て水素侵食を起こす．水素侵食とは，鋼中に侵入した水 素と安定度の低い炭化物とが化学反応を起こし, メタン 気泡を生成し，同時に脱炭も進行して，ついは割れに 至る現象をいら ${ }^{1)}$. 石油精製やアンモニア合成などの化 学プラントでは, この水素侵食による事故例や損傷例 が，今までに数多く報告されてきた 2) 8).

現在のところ，水素侵食の子知方法は確立されておら ず，経験に基ついて作製された NELSON 線図" て，プラント材料の選定をおこならのが唯一の防止策で ある.しかも， NELSON 線図は過去数次の改訂がおこな われており，今後も改訂の可能性があるため，プラント 材料の水素侵食対策に苦虑しているのが実状である.

著者らは, 水素侵食は鋼中に侵入する水素量と密接な 関係があると考えている. 例えば, 炭素鋼での水素侵食 が起こる臨界水素量は約 $0.6 \mathrm{ppm}, \mathrm{Cr}-\mathrm{Mo}$ 鋼でのそれ は $2.4 \sim 4.3 \mathrm{ppm}$ と見積もつている10). このよらな定量 的検討に資するため, 本研究では, 電気化学的に鋼中水 素量を測定する方法であつて, 高温 $(673 \sim 773 \mathrm{~K})$ で使
えるものの開発をめざした。

この電気化学的測定法には, 装置が簡単で, 水素量の 検出感度が高く, 連続測定が容易などの数々の利点があ るが，これまでのところ，この方法は電解質に水溶液を 用いることから，常温近傍温度での使用に限られてい た. 一方高温での鋼中の水素量測定 ${ }^{11)}$ 13) や水素透過の

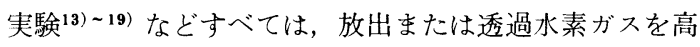
気密性の真空下で分析する気相法によつていた．気相法 には，装置が大がかりとなる，連続測定が困難である， 検出感度に難がある, などの欠点があるため，この方法 のプラントへの適用例はない.

\section{2. 実 験 方 法}

\section{$2 \cdot 1$ 電気化学測定法の原理}

電気化学的測定法は, Fig. 1 に示す原理に基ついて いる.すなおち, 水素供給面（水素侵入面）でカソード 反応により水素を発生し, 試料中に侵入・透過する水素 を他面においてイオン化 $\left(\mathrm{H} \rightarrow \mathrm{H}^{+}+\mathrm{e}^{-}\right)$させ，その際 のアノード電流を測定することにより，試料中の水素の 拡散係数 $D$ および水素供給面での水素含有量 $C_{0}$ を得 る力法である20). したがつて, アノード電流から透過水

昭和 60 年 10 月本会講演大会にて発表 昭和 60 年 5 月 27 日受付 (Received May 27, 1985)

* 大阪府立大学. [. 学部 工博 (College of Engineering, University of Osaka Prefecture, MozuUmemachi Sakai Osaka 591)

*2 大阪府立大学大学院 (現：日新製鋼(株)) (Graduate School, University of Osaka Prefecture, Now Nisshin Steel Co., Ltd.)

*3 大阪府立大学大学院 (Graduate School, University of Osaka Prefecture) 


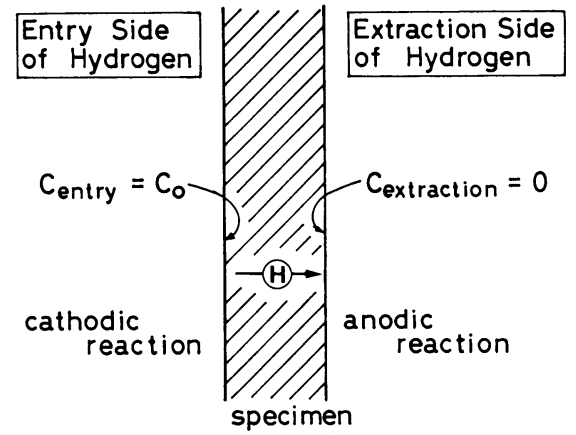

Fig. 1. Principle of hydrogen permeation technique.

素量を感度高くうるには, 水素イオン化電流以外のア, 一ド電流, 例えば試料溶解に伴うアノード電流を極力小 さくし, さらに試料中の水素の拡散速度よりも水素イオ ン化速度を大きくすることが重要である. すなわち $C_{0}$ はカソード電流密度により, また水素イオン化速度はそ の面に与えるアノード電位一水素引抜電位一によつて制 御するのである。

上述の $D$ および $C_{0}$ は次のように求められる.なお 本実験では，後述のように円筒状試料を用い，その外径 $b$ の表面で水素を供給し, 内径 $a$ 表面で水素を引抜く.

Fig. 2 に示すように, 水素供給のカソード電流を矩形 パルス状に与え, それに伴ら透過電流の経時変化一透過 電流の増加 (Build up) および減少 (Decay) 過程一を 測定する.これら雨過程での試料中の水素濃度分布は, 時間とともに変化し，ついには定常状態に至る(Fig. 3). なお Fig. 3 の横軸は円柱座標での半径方向をとつてい る.

通常, 水素の拡散は FICK の第 2 法則によつて取り扱 万. 円筒状試料の非定常状態の Build up および Decay 過程の拡散解は，それぞれ(1)式および(2)式で与 えられる21).

$$
\begin{aligned}
\frac{J_{t}}{J_{\infty}}= & 1+2 \ln k \sum_{n=1}^{\infty} \frac{J_{0}\left(\alpha_{n}\right) J_{0}\left(k \alpha_{n}\right)}{J_{0}^{2}\left(\alpha_{n}\right)-J_{0}^{2}\left(k \alpha_{n}\right)} \\
& \times \exp \left(-\alpha_{n}^{2} \tau\right) \quad \ldots \ldots \ldots \ldots \ldots \ldots \ldots \ldots \ldots \ldots \ldots \ldots \ldots \ldots \ldots \ldots \ldots \ldots \ldots \ldots \ldots \\
\frac{J_{t}}{J_{\infty}}= & -2 \ln k \sum_{n=1}^{\infty} \frac{J_{0}\left(\alpha_{n}\right) J_{0}\left(k \alpha_{n}\right)}{J_{0}^{2}\left(\alpha_{n}\right)-J_{0}^{2}\left(k \alpha_{n}\right)} \\
& \times \exp \left(-\alpha_{n}^{2} \tau\right) \quad \ldots \ldots \ldots \ldots \ldots \ldots \ldots
\end{aligned}
$$

また定常状態での解は，(3) 式で与えられる.

$$
J_{\infty}=\frac{F D C_{0}}{a \ln k}
$$

ここに, $J_{t}$ は時間 $t$ での透過電流, $J_{\infty}$ は定常透過電 流, $\alpha_{n}$ は $r=a$ の時の $J_{0}\left(r \alpha_{n}\right) Y_{\mathbf{0}}\left(b \alpha_{n}\right)-J_{0}\left(b \alpha_{n}\right) Y_{0}$

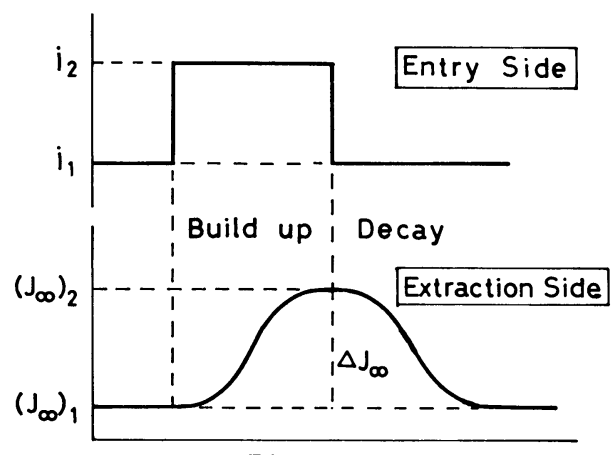

T ime

Fig. 2. Schematic representation of build up and decay permeation transients detected at the extraction side accompanying with different cathodic current applied to the entry side. $J_{\infty}$ shows the steady state permeation current.
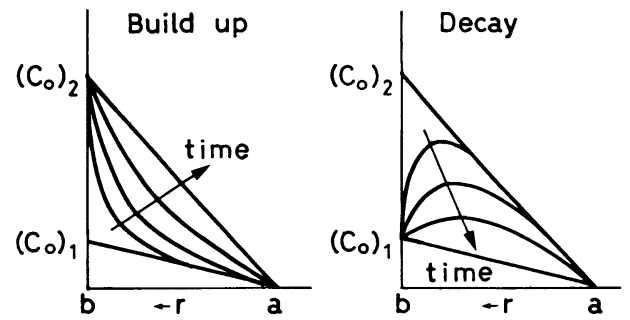

Fig. 3. Concentration distributions of hydrogen in hollow cylindrical specimen at various time. $a$ and $b$ show inner and outer radii, respectively.

Table 1. Chemical composition of the steel (wt \%).

\begin{tabular}{cccccc}
\hline $\mathrm{C}$ & & & & & \\
$(\mathrm{wt} \%)$ \\
\hline 0.19 & 0.22 & 1.00 & 0.018 & 0.012 & 0.015 \\
\hline
\end{tabular}

$\left(r \alpha_{n}\right)=0$ の根, $J_{0}$ および $Y_{0}$ はそれぞれ 0 次の第 1 種 および第 2 種ベッセル関数, $k=b / a, F$ は FARADAY 定 数, $D$ は試料中水素の拡散係数, $C_{0}$ は水素供給面での 水素含有量, $\tau$ は次式で与えられるものである.

$$
\tau=\frac{D t}{a^{2}}
$$

(1)式，（2)式から計算してえた理論曲線と実測の透過 曲線との比較から $D$ が得られる.なお理論曲線は $\alpha_{1}$ $\sim \alpha_{5}$ の根を用いて計算した. ついでその $D$ を用いて ( 3 ) 式から $C_{0}$ が得られる.

\section{$2 \cdot 2$ 試料および測定装置}

実験に用いた鋼の化学組成を Table 1 に示す. $50 \mathrm{~mm}$ 直径の棒鋼から, Fig. 4 に示す円筒形状の試料に切削 し仕上げた. 試料の内半径 $a$ は $12.5 \mathrm{~mm}$ 一定にし, 外 


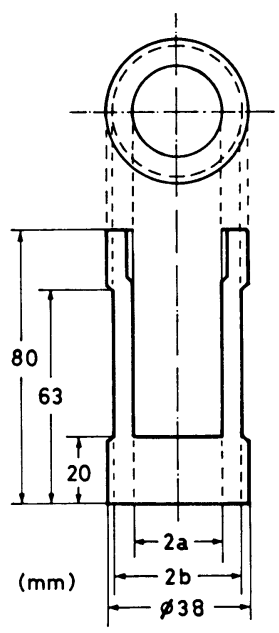

Fig. 4. Experimental specimen.

Table 2. Dimension of specimen.

\begin{tabular}{cccc}
\hline$a(\mathrm{~mm})$ & $b(\mathrm{~mm})$ & $b-a(\mathrm{~mm})$ & $k=b / a$ \\
\hline 12.5 & 14.5 & 2 & 1.16 \\
\hline 12.5 & 16.5 & 4 & 1.32 \\
\hline 12.5 & 19.0 & 6.5 & 1.52 \\
\hline
\end{tabular}

半径 $b$ を変え, 肉厚を 2,4 および $6.5 \mathrm{~mm}$ の三通り になるよらにした（Table 2)。なお試料底の厚さは肉 厚の 3 倍以上にした。これより, 底面での透過速度が側 面でのそれの約 10 倍異なり, 底面での水素透過を無視 した。試料の外面および内面をエメリ一紙一 一で研磨し，内面はさらに電解研磨ののち金めつきを施 した，その金めつきは，酸性金めつき液（ジャパンロナ ール(株)製を用い， $100 \mathrm{~A} / \mathrm{m}^{2}$ の電流密度で $50 \mathrm{~s}$ おこ なつた．金めつき厚さは約 $0.15 \mu \mathrm{m}$ であつた．分極曲 線の測定には, 棒鋼から $50 \times 10 \mathrm{~mm}$, 厚さ $2 \mathrm{~mm}$ の板 状に切り出し試料とした。

実験装置の概略を Fig. 5 に示す．Fig. 5 中 (A) 少 よび (B)はそれぞれ水素供給側および水素引抜側であ る. 電解質として, (A), (B) 両浴とも溶融苛性ソータ （融点 $=595 \mathrm{~K}$ ) を用いた。

水素供給は, 試料極に対して同心円上に配置した 4 本 のグラファイト棒を対極にして, $313 \mathrm{~K}$ の水浴を通した Ar ガスを吹き込及ながら，カソード電流を流しておこ なつた。なおガス流量は $1.7 \times 10^{-6} \mathrm{~m}^{3} / \mathrm{s}$ とした。カソ ード電流は, $20 \sim 200 \mathrm{~A} / \mathrm{m}^{2}$ の電流密度を選び22) ガルバ ノスタットで供給した。水素引抜部においては, ポテン ショスタットにて試料表面を一定の水素引抜電位に保 ち，透過電流の経時変化を記録した．比較電極には安定

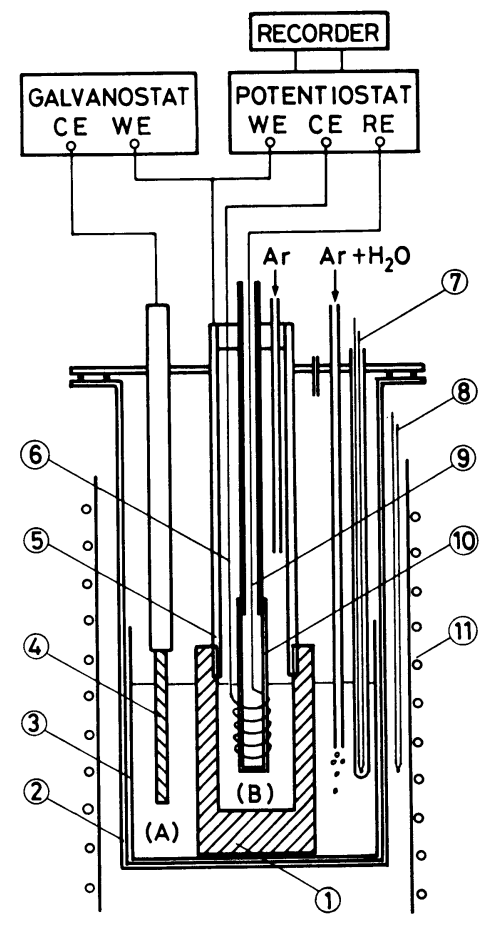

1: Specimen, 2: Stainless steel tube, 3: Alumina crucible, 4: Graphite rod, 5: Stainless steel tube, 6: Nickel wire, 7, $8:$ Thermocouple, 9: Stainless steel wire, $10:$ Stabilized zirconia tube, 11: Furnace

Fig. 5. Experimental apparatus and electronic circuit.

化ジルコニア管に白金ペーストを焼付けた，いわゆる酸 素（空気）電極を，対極にはニッケル線を用いた。

試料にステンレスパイプ（SUS 304）をねじ込み，試 料極とした。なお（B）での溶融苛性ソーダの深さは約 $40 \mathrm{~mm}$ であつた.

電解槽は, 673 または $773 \pm 1 \mathrm{~K}$ に保つた。

\section{3. 実験結果および考察}

\section{1 溶䇛苛性ソーダ中での試料の分極曲線}

溶融苛性ソーダ中での試料のカソードおよびアノード 分極曲線を Fig. 6 に示す.なおアノード分極曲線は金 めつき試料を用いてえた。

カソード分極曲線は三つの部分から成つている．約 $-2.3 \mathrm{~V}$ (vs $\left.\mathrm{Air} / \mathrm{O}^{2-}\left(\mathrm{ZrO}_{2}\right)\right)$ 以下の曲線は溶融苛性 ソーダから金属ナトリウムの生成（(5)式）に伴らもの である23).

$$
\mathrm{Na}^{+}+\mathrm{e}^{-} \longrightarrow \mathrm{Na}
$$

この $\mathrm{Na} / \mathrm{Na}^{+}$の電位はかなり安定なため,この電位を 用いて数本のジルコニア管の電位，すなわち空気 $/ \mathrm{O}^{2-}$ 


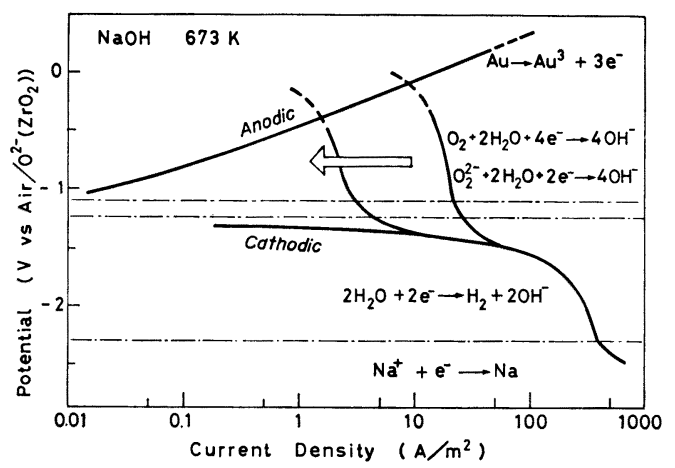

Fig. 6. Polarization curves of the steel in molten sodium hydroxide at $673 \mathrm{~K}$.

$\left(\mathrm{ZrO}_{2}\right)$ の電位を較正した. -2.3 約 $-1.2 \mathrm{~V}$ の曲線 は水素発生反応（(6) 式）に伴うものである ${ }^{23)}$.

$$
2 \mathrm{H}_{2} \mathrm{O}+2 \mathrm{e}^{-} \longrightarrow \mathrm{H}_{2}+\mathrm{OH}^{-}
$$

この電位域での電流を用いて水素を発生させ水素供給を おこなつた， $-1.2 〜-0.2 \mathrm{~V}$ での曲線は，溶融苛性ソ 一ダ中の酸素または過酸化物イオンの還元（(7)式）に 伴らものである ${ }^{23)}$.

$$
\begin{aligned}
& \mathrm{O}_{2}+2 \mathrm{H}_{2} \mathrm{O}+4 \mathrm{e}^{-} \longrightarrow 4 \mathrm{OH}^{-} \\
& \mathrm{O}_{2}^{2-}+2 \mathrm{H}_{2} \mathrm{O}+2 \mathrm{e}^{-} \longrightarrow 4 \mathrm{OH}^{-}
\end{aligned}
$$

なお Fig. 6 中のアノード分極曲線は, めつき金の溶 出によるものであろら。

さて, 空気開放下の電解質液中では，（）式に伴ら電流 はかなり大きい，そのような場合，アノード，カソード 両曲線の交点の電位は高くなり，その結果アノード電位 では水素イオン化反応以外のアノード電流が大きくなる ため, 水素検出感度は悪くなる. そこで電解槽の気密性 を高め, アルゴンガスにて脱気すると，この電位域のカ ソード電流は Fig. 6 中矢印のように減少する。そのよ らな状態で，水素引抜電位を $-1.0 \sim-0.4 \mathrm{~V}$ vs Air/ $\mathrm{O}^{2-}\left(\mathrm{ZrO}_{2}\right)$ に設定した.

\section{$3 \cdot 2$ 水素透過曲線}

水素透過曲線の一例を Fig. 7 に示す. 図中矢印は水 素供給電流（カソード電流）を变化した時点を示す. 水 素供給電流 50 と $100 \mathrm{~A} / \mathrm{m}^{2}$ 間の Build up, Decay 過 程での透過電流の変化量, $\Delta J_{\infty}\left(=\left(J_{\infty}\right)_{100}-\left(J_{\infty}\right)_{50}\right)$ は, いずれも約 $3.95 \mathrm{~mA}$ と同じである.

Fig. 8 には，(1)および (2) 式から計算した $J_{t} / J_{\infty}$ 対 $\tau$ の理論曲線（実線）と実測データを $J_{t} / J_{\infty}$ の形に 規格化し $t$ に対してプロットして，両者の比較を示 す.なお理論曲線と実測データの両者が $J_{t} / J_{\infty}=0.5$ で 一致するよらに，実測データを水平に移動してプロット した. 試料肉厚 $(b-a) 6.5 \mathrm{~mm}$ の場合, 両者の一致は

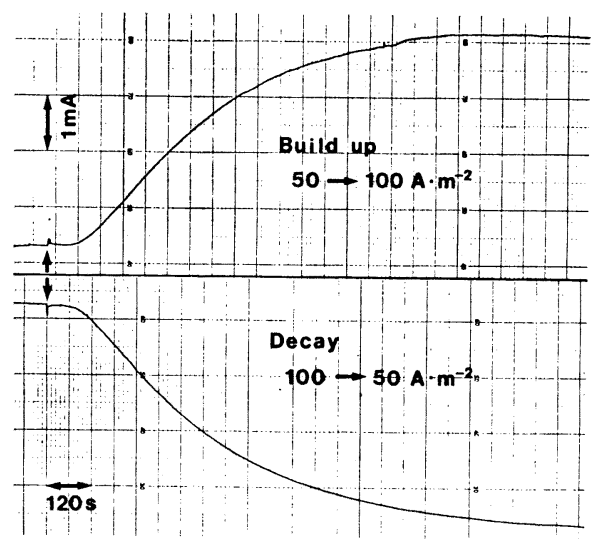

Fig. 7. Typical permeation transients at $673 \mathrm{~K}$. Extraction potential is $-0.6 \mathrm{~V}$ vs $\mathrm{Air} / \mathrm{O}^{2-}\left(\mathrm{ZrO}_{2}\right)$. Specimen thickness $(b-a)$ is $4 \mathrm{~mm}$.
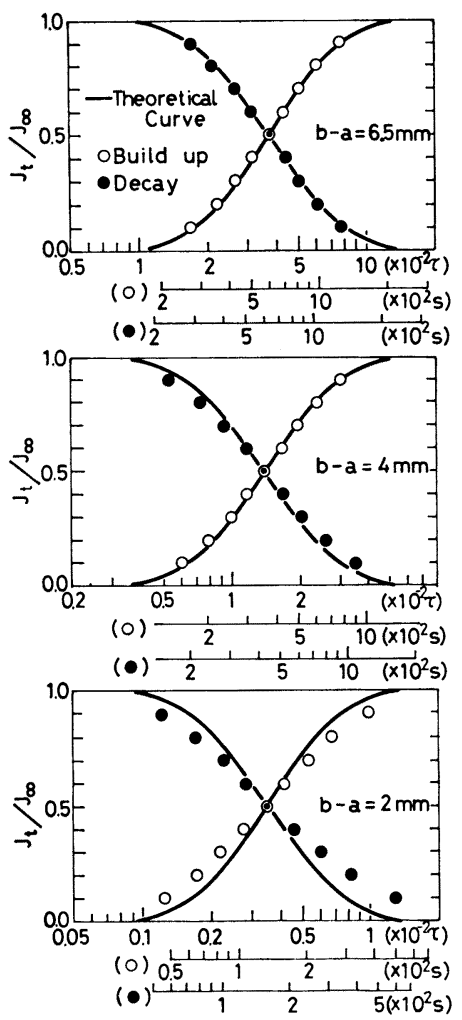

Fig. 8. Comparison between theoretical curves and experimental curves in build up and decay transients in specimens with various thickness $(b-a)$.

極めてよい。この結果は, 理論解をらる際の境界条件 21) を満たすものであり, 引抜面に到着した水素をすばやく イオン化でき，水素引き抜きが良好におこなえたことを 


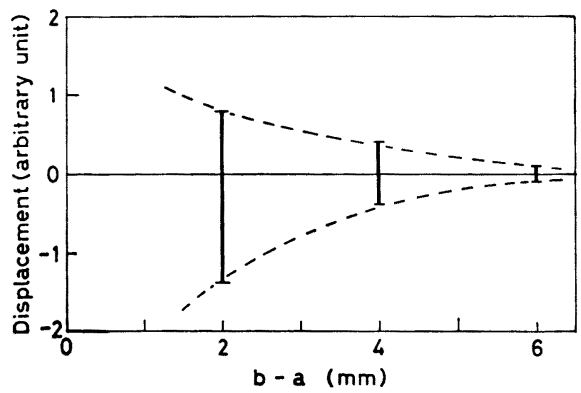

Fig. 9. Relationship between displacement of experimental curve from theoretical curve and specimen thickness.

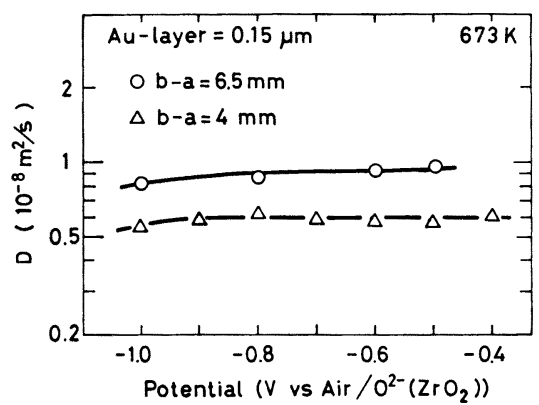

Fig. 10. Relationship between diffusivity of hydrogen in steel and extraction potential.

意味する. しかし肉厚が小さくなるに従い, 両者の一致 は悪くなる傾向にある. そこで, 各 $J_{t} / J_{\infty}$ での理論曲 線とデータのずれを試料肉厚に対して示すと Fig. 9 の よらになる. 肉厚 $2 \mathrm{~mm}$ の場合のずれは Build up, Decay 過程ともかなり大きい。これは金中水素の透過 速度が小さいため24), 肉厚が小さくなると試料中の水素 透過に対するめつき金の影響が無視できなくなるためで あろら・

いずれの肉厚の場合も, $J_{t} / J_{\infty}=0.5$ での $t$ は Buildup よりDecay 過程の方がやや大きい。(4)式に示した

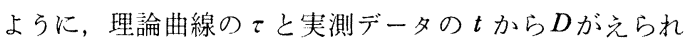
るのであるから,この結果は Build up, Decay 過程で Dが異なることを意味する。

\section{$3 \cdot 3$ 水素引き抜きと電位の関係}

理論曲線と奏測の水素透過曲線での比較から，(4)式 を用いてえた $D$ と引抜電位の関係をFig. 10 に示す. 3.2 で記したように Build up と Decay 過程で $D$ は 幾分異なるが，Fig. 10 にはそれら両 $D$ の平均值をブ ロットした。なお肉厚 $2 \mathrm{~mm} の$ 場合, 透過曲線は理論曲 線との一致が悪かつたので除外した.いずれの肉厚の場 合も $D$ は引抜電位に依存せずほぼ一定である．肉厚 4 $\mathrm{mm}$ の場合の $D$ が $6.5 \mathrm{~mm}$ のそれより小さいのは, 先

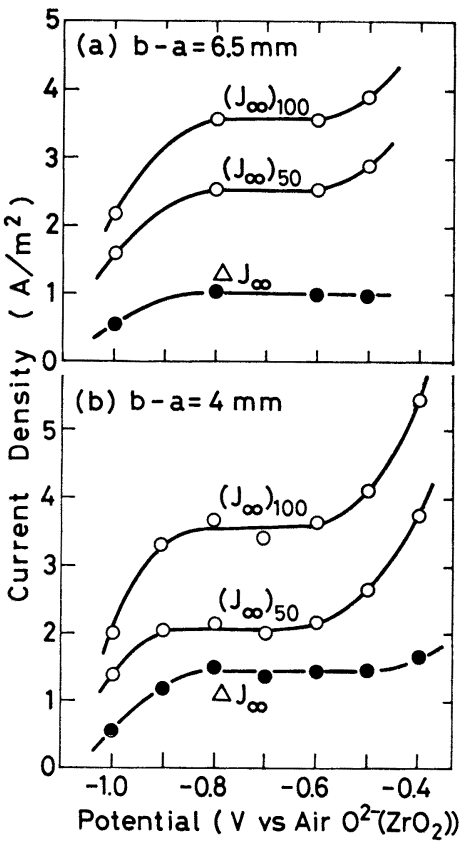

Fig. 11. Relationship between permeation current density and extraction potential for two cathodic current densities, 50 and $100 \mathrm{~A} / \mathrm{m}^{2}$.

$J J_{\infty}$ is the difference of the two steady state permeation current densities.

述の水素透過に対するめつき金の影響が無視できなくな つたためであろら。なお，カソード電流を種々変えた先 験から，D浔ソード電流に依存しないことがわかつ た。

カソード電流を 50 または $100 \mathrm{~A} / \mathrm{m}^{2}$ と一定にした場 合の定常透過電流 $\left(J_{\infty}\right)$ と引抜電位の関係を Fig. 11 に示す. $-0.8 \sim-0.6 \mathrm{~V}$ vs $\mathrm{Air} / \mathrm{O}^{2-}\left(\mathrm{ZrO}_{2}\right)$ 間ではほ ぼ同じ $J_{\infty}$ であるが, $-0.9 \mathrm{~V}$ 以下では $J_{\infty}$ は減少 し， $-0.4 \mathrm{~V}$ 以上では増加する.さらにカソード電流を 50 と $100 \mathrm{~A} / \mathrm{m}^{2}$ の間で変化させた際の透過電流の変化 量の Build up, Decay 両過程での平均值を $J_{\infty} と し$ て Fig. 11 に一緒にプロットした. $-0.9 \mathrm{~V}$ 以下におい ては JJのも減少する. したがつて, この電位域では水 素を十分引き抜けていないことを意味する。一方，-0.6 $\mathrm{V}$ 以上では，JJのにおいてはほとんど電位依存性は認 められない、したがつて，この電位域での $J_{\infty}$ のみか けの増加は水素イオン化反応とは別のアノード電流が重 畳したためと考えられる。

以上より，水素引き抜きの適切な電位は， -0.8 $-0.6 \mathrm{~V}$ vs $\mathrm{Air} / \mathrm{O}^{2-}\left(\mathrm{ZrO}_{2}\right)$ と結論できる。

この電位域での $J_{\infty}$ から，（3)式を用いて本実験で 


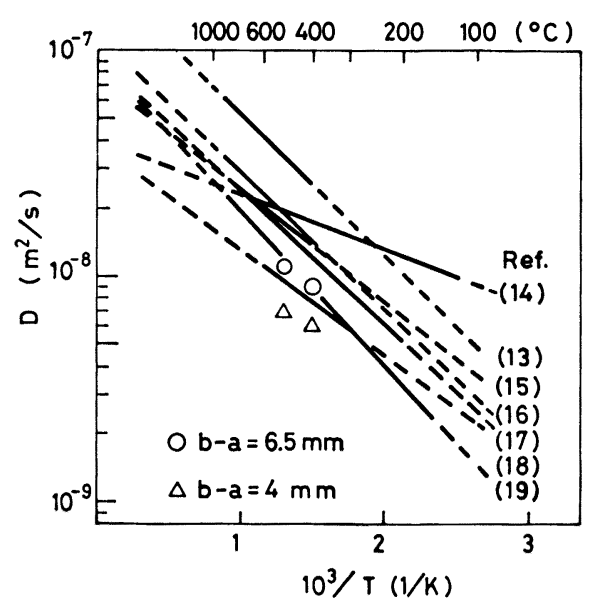

Fig. 12. Arrehenius plots of diffusivities of hydrogen in the steel.

のカソード電流での $C_{0}$ を計算してみると, 肉厚 4 およ び $6.5 \mathrm{~mm}$ いずれもほぼ同じで，50，100 および 200 $\mathrm{A} / \mathrm{m}^{2}$ の場合でおのおの $1.8,2.6$ および $3.2 \mathrm{ppm}$ と なつた。

\section{4 鋼中水素の拡散係数}

本実験でえた鋼中水素の払散係数 $(D)$ を温度に対し てプロットするとFig. 12 のようになる. 同図中には気 相法による，透過実験13) 17) および放出実験 ${ }^{17) ~ ~ 19) ~ て ゙ え ~}$ られた他の研究者の $D$ 值も一緒に示した．気相法によ る $D$ 值にかなりの違いが認められ，いずれが正しい $D$ 值か現在のところわからないが，本実験の肉厚 6.5 $\mathrm{mm}$ の $D$ 值は気相法でえられた值に一致するようであ る.したがつて, 本電気化学的測定法は, 高温・高圧水 素ガスを用いた場合とほぼ同じ結果がえられることが判 明した。

\section{5 水素量の検出感度}

3.3 で結論した水素引拔電位においては，Fig. 6 か らわかるよらに水素イオン化反応以外のアノード電流を $0.5 \mathrm{~A} / \mathrm{m}^{2}$ 以下に抑えることができる. (3) 式を用いて この $0.5 \mathrm{~A} / \mathrm{m}^{2}$ に相当する $C_{0}$ を評価してみると, 肉厚 4 および $6.5 \mathrm{~mm}$ の試料でそれぞれ約 0.4 および 0.3 ppm となる，立たFig. 7 からわかるよらに，透過電流 の測定誤差は十分 $0.3 \mathrm{~mA}$ 以下であり，この誤差は透過 電流から水素イオン化反応以外のアノード電流を差引い た $\Delta J_{\infty}$ の場合も同じである(水素引抜面積 $3.2 \times 10^{-3}$ $\left.\mathrm{m}^{2}\right)$ ので, 本測定の水素量検出感度は肉厚 4 および 6.5 $\mathrm{mm}$ の試料とも約 $0.07 \mathrm{ppm}$ と見積もられ，0.1 ppm以 下といらことになる。

この検出感度は, 材料中の $D$ および肉厚, 直径に依
存するが，高温・高圧プラントで実際されている管のほ とんどは外径 $10 \mathrm{~cm}$, 肉厚 $6 \mathrm{~mm}$ 以上のものであり, また Cr-Mo 鋼中の $D$ は炭素鋼中のそれに近いことか ら, 実機プラントに適用した場合の検出感度も $0.1 \mathrm{ppm}$ 以下とみなすことができる. 水素侵食を起こす水素含有 量は炭素鋼で約 $0.6 \mathrm{ppm}$, Cr-Mo 鋼で $2.4 \sim 4.3 \mathrm{ppm}$ と見積つている10)ので，本測定の検出感度はそれらより 十分高く, 本測定法は水素侵食の予知に十分適応するも のであろら。

\section{4. 結言}

溶融苛性ソーダを電解質に用いた電気化学的測定法を 使つて, 高温 $(673 \sim 773 \mathrm{~K})$ での水素の引き抜きをおこ なつた結果, 以下の結論がえられた。

(1) 水素引き抜きの最適電位は, $-0.8 \sim-0.6 \mathrm{~V}$ vs $\mathrm{Air} / \mathrm{O}^{2-}\left(\mathrm{ZrO}_{2}\right)$ である。

(2) 肉厚 $6.5 \mathrm{~mm}$ の試料の水素透過曲線は理論曲線 によく一致した.この結果は, 拡散・透過する水素を水 素引抜面ですばやくイオン化しえたものとみなされ，水 素引抜が良好に扣こなえたことを意味する.

(3) 本実験でえた肉厚 $6.5 \mathrm{~mm}$ の鋼中水素の払散係 数は, 気相法でえられた他の研究者の值とよく一致し た。

（4）本実験における水素量の検出感度は $0.1 \mathrm{ppm}$ 以下である。

（5）以上より, 従来実験室的に気相法でおこなわれ てきた高温での水素検出が電気化学測定法で十分おこな えることが判明した．さらに本水素検出方法は，実機ブ ラントの水素侵食の予知に有用であることも判明した.

本研究の遂行にあたり, 有益な助言を賜つた京都大学 工学部の伊藤靖彦先生に深謝します. 本研究には文部省 科学研究費 (試験研究 (2)) の補助を受けた。試料は株 式会社神戸製鋼所から,さらにジルコニア管は日本化学 陶業株式会社から提供されたものである．付記して謝意 を表する。

\section{交献}

1) 例之ば，椿野晴繁，山川宏二：鉄と鋼，71 (1985), p. 1070

2 ）石塚 宽, 千葉隆一：日本金属学会会報，4 (1965), p. 761

3 ) 石塚 寛, 千葉隆一：鉄と鋼, 56 (1970), p. 93

$4)$ 山川宏二: 材料, 25 (1976), p. 1110

5 ) 渡辺十郎: 鉄と鋼, 64 (1978), p. 1020

6 ) 渡辺十郎, 千葉隆一: 溶接学会誌, 48 (1979), p. 167

7 ) 設計 · 保安技術者のための高温 - 高生水素侵害事 例の収集と整理（日本材料学会腐食防食部門委員 会編）(1980) [日本材料学会] 
8 ) 井上威恭: 版力容器の信頼性シンポジウム, 日本 压力容器研究会議 $(1984)$, p. 3 [日本鉄鋼協会]

9) API Publication 941, Third ed. (1983-5)

10）椿野晴繁，山川宏二：防食技術，33 (1984), p. 159

11) $D . C$. Camichael, $J . R$. Hornaday, $A . E$. Morris and $N$. A. Parlee: TMS-AIME, 218 (1969), p. 607

12) O. D. Gonzalez: 同上, 245 (1969), p. 607

13) $W$. Geller and $T-H$. Sun: Arch. Eisenhüttenwes., 21 (1950), p. 423

14) W. L. BRYAN and B. F. Dodge: AIChE J., 9 (1963), p. 223

15) C. Sykes, $H$. H. Burton and $C$. C. Gegg: JISI, 156 (1947), p. 173

16) $H$. Schunck and $H$. Taxhet: Arch. Eisenhüttenwes., 30 (1959), p. 661
17) $W$. Eichenauer, $H$. Künzig and $A$. Pebler: Z. Metallkd., 49 (1958), p. 220

18) F. R. Coe and J. Moreton: JISI, 204(1966), p. 366

19) T. M. Stross and F. C. Tompkins: J. Chem. Soc. London (1956), p. 230

20) $M . A . V$. Devanathan and $Z$. Stachurski: Pro. Roy. Soc. London, A270 (1962), p. 90

21) $H$. Tsubakino and $K$. Yamakawa: Bull. Univ. of Osaka Pref., A33 (1984), p. 73

22) $H$. Tsubakino, $A$. Ando, $T$. Masuda and $K$. Yamakawa: Trans. ISIJ, 25 (1985), p. 999

23) $Y$. Ito, $H$. KaiYa and $S$. Yoshizawa: Energy Development in Japan, 3 (1981), p. 153

24) G. M. Pressouyre: Hydrogen Problems in Steels, ed. by $C$. $G$. Interrante and $G$. $M$. Pressouyre, Ohio (1982), p. 18 [ASM] 